\title{
Correction to: Mechanical analysis and characterization of IGUs with different silicone sealed spacer connections - Part 1: experiments
}

\author{
Chiara Bedon ( Claudio Amadio
}

Published online: 10 September 2020

(C) Springer Nature Switzerland AG 2020

\section{Correction to:}

Glass Struct Eng.

https://doi.org/10.1007/s40940-020-00122-w

The article title was incorrect in the initial online publication. The original article has been corrected.

Publisher's Note Springer Nature remains neutral with regard to jurisdictional claims in published maps and institutional affiliations.

The online version of the original article can be found under https://doi.org/10.1007/s40940-020-00122-w.

C. Bedon $(\varangle) \cdot$ C. Amadio Department of Engineering and Architecture, University of Trieste, Piazzale Europa 1, 34127 Trieste, Italy

e-mail: chiara.bedon@dia.units.it 